\title{
Validation study of a scale for assessing three personality functional dimensions among Venezuelan HIV-positive patients
}

This article was published in the following Dove Press journal: Psychology Research and Behavior Management

\author{
José Moral de la Rubia,' \\ Gerymar Pastora Colombo \\ Andrade, ${ }^{2}$ Arelys Carolina \\ Torres Yépez, ${ }^{2}$ Víctor \\ Manuel López Guerra, ${ }^{3}$ Julio \\ Alfonso Piña López, ${ }^{4}$ José \\ Luis Ybarra Sagarduy ${ }^{5}$
}

'Faculty of Psychology, Autonomous University of Nuevo Leon, Monterrey, Nuevo Leon, Mexico; ${ }^{2}$ Department of Psychology, West-Central University "Lisandro Alvarado", Barquisimeto, Lara, Venezuela; ${ }^{3}$ Department of Psychology, Private Technical University of Loja, San Cayetano, Loja, Ecuador; ${ }^{4}$ Independent Researcher, Hermosillo, Sonora, Mexico; ${ }^{5}$ Unit of Social Work and Sciences for Human Development, Autonomous University of Tamaulipas, Ciudad Victoria, Tamaulipas, Mexico
Correspondence: José Moral de la Rubia Facultad de Psicología, Universidad Autónoma de Nuevo León. Dr. Carlos Canseco No. 110 y Dr. Eduardo Aguirre Pequeño, Colonia Mitras Centro, C.P. 64460, Monterrey, Nuevo León, México Email jose_moral@hotmail.com
Background: Personality has been recognized as a key variable in the prediction of treatment adherence and health care behaviors in patients living with chronic diseases.

Purpose: In order to contribute to the prediction of treatment-adherence behaviors among HIVpositive patients, this study aimed to test the metric properties of the 12-item Stress-Related Situations Scale (SRSS-12), which assesses four interactive styles of personality related to stressful situations when receiving treatment for a chronic disease.

Patients and methods: This cross-sectional study was performed with a nonprobability sampling between May and June 2016. The SRSS-12 was fulfilled by 186 out of 400 HIV-positive patients receiving attention through the regional program for HIV -sexually transmitted diseases control in the State of Lara, Venezuela (sample proportion $=0.465$ ). The participants were young adults ( $\mathrm{X}=34.9$ years), predominantly men (80.1\%), and single (76.3\%). Data analysis included exploratory factor analysis and confirmatory factor analysis, assessment of internal consistency, and description of distributions.

Results: The exploratory factor analysis yielded a three-factor structure: Tolerance to Frustration and Ambiguity, Follow-up of Instructions and Impulsivity, and Decision Making. Through confirmatory factor analysis, this model showed an acceptable fit to the data. The three factors showed convergent and discriminant validity and internal consistency from acceptable to high. The factor scores did not follow a normal distribution.

Conclusions: The three-factor model for the SRSS-12 showed validity and internal consistency among Venezuelan HIV-positive patients. Scaled scores for factors can be developed using percentile scores.

Keywords: tolerance to frustration, tolerance to ambiguity, impulsivity, interactive style of personality, stress

\section{Introduction}

The study of personality is key in the efforts to predict treatment adherence and health care behaviors, as well as to evaluate their influence on the management and clinical control of chronic disease (eg, diabetes, heart failure, cancer, and HIV/AIDS.). ${ }^{1}$ Traditionally, the concept of personality has been defined as traits or stable predispositions, including dimensions such as conscientiousness, extraversion, introversion, submission, dominance, neuroticism, and psychoticism. ${ }^{2-4}$ Based on these dimensions, different studies have been conducted in the last two decades in order to prove the relationship between personality and treatment-adherence behaviors, as well as the impact of personality on quality of life and the clinical progression of chronic diseases, such as HIV/AIDS..$^{5-7}$ 
Nevertheless, the problem underlying in this definition is that persons are grouped into preestablished categories, considering them as equivalent members of the same class; furthermore, with such a classification, reactive forms of behavior (eg, physiological response patterns and socially valued behaviors) are analyzed as general behavioral predispositions, but not as modes of interaction between individuals and contextual situations. ${ }^{8}$ Following Ribe's proposal of personality, ${ }^{8,9}$ and according to Ryle's analytic philosophy, ${ }^{10}$ the terms coming from the ordinary language for describing psychological events can be grouped into different logical categories, known as dispositional categories; these have to do with sets or collections of past or present events, not with particular past or present events. In psychology, the terms of ordinary language are functionally related to, or are a consequence of, the capacities (what a person can competently do), propensities (why the person does certain things and in what social circumstances), and tendencies (how is it that the person behaves consistently over time and between different situations).

The concept of personality describes the particular modes of behavior (as interactive styles), as a tendency along the time and in situations that are not socially valued, that is, in situations in which the person is not expected to do something or behave in a certain way. Therefore, the concept of personality allows us to identify and predict how a person interacts consistently with other persons in different situations. The emphasis is on how each person behaves at the individual level, according to a unique functional profile. ${ }^{8,11}$ From this theoretical perspective, experimental research has included the study of interactive styles such as risk tendency, ${ }^{12}$ persistence to achievement, ${ }^{13}$ tolerance to frustration,,${ }^{14}$ and tolerance to ambiguity. ${ }^{15}$

Based on this theoretical proposal, some years ago, Piña and Sánchez-Sosa ${ }^{16}$ developed a psychological model for the research of treatment-adherence behaviors in persons living with chronic diseases, including the design and validation of two self-administered instruments. The first one is for measuring two psychological variables: motives and behavioral competencies related to the practice of treatment adherence and health care behaviors. ${ }^{17}$ The second one is for measuring four interactive styles of personality related to stressful situations when receiving treatment for a chronic disease: 1) Decision Making (DM) is defined as a style of behavior with which a person faces one or more situations in which a response option is demanded and the person perceives it, or a response option is demanded and the person does not perceive it, or the person perceives a demand to response that does not exist; 2) Tolerance to Ambiguity (TA) is defined as a situation in which there is a demand to do something and the person behaves, but there is no relationship between the demand and the consequences that are obtained when behaving; 3 ) Tolerance to Frustration is defined as a situation in which a person behaves in a certain way and the consequence that is obtained is less than expected, is delayed, not delivered, or requires for a greater execution; and 4) Impulsivity is defined as a lack of correspondence between the stimuli and the reactions to them, in situations in which their relationships are not homogeneous. ${ }^{9}$

This proposal of four interactive styles of personality gave rise to 12-item Stress-Related Situations Scale (SRSS-12). ${ }^{18}$ The validation study of the SRSS-12, performed among Mexican HIV-positive patients, showed a three-factor structure that explained $70.5 \%$ of the total variance: DM, TA, and TF/I. ${ }^{19}$ Recently, the SRSS-12 was adapted and validated in women diagnosed with breast cancer in Peru. The exploratory factor analysis (EFA) yielded two factors that explained the $59.9 \%$ of total variance: Tolerance to Frustration/Ambiguity (TFA) (raw Cronbach's alpha $=0.88$ ) and DM (raw Cronbach's alpha $=0.70) .{ }^{20}$ The three-factor model was not tested using confirmatory factor analysis (CFA) in this last research. Because of these results, we consider that the process of adaptation and validation in other countries can contribute to clarifying the factor structure of the scale, verify its reliability, and deepen its application to predict the role of personality in treatment adherence and health care behaviors among people living with a chronic disease.

Thus, the objectives of this study were to test the expected model of three factors, prove the convergent and discriminate validity of these factors, verify the internal consistency of the scale and its factors, and describe the distributions of factor scores. In this study, we hypothesized that a three-factor structure, like that obtained in the original validation study in Mexico, ${ }^{19}$ could be reproduced in Venezuela: TF/I (items 1, 2, 3, 4, 8, and 9); TA (items 5, 6, and 7); and DM (items 10, 11, and 12). Nevertheless, there may be a lack of discriminant validity between the TF/I and TA factors, which would bring them together as a single factor within a two-factor model as the model observed in Peru. ${ }^{20} \mathrm{~A}$ high (raw Cronbach's alpha $\left.\geq 0.80\right)^{20}$ or a very high (raw Cronbach's alpha $\geq 0.90)^{19}$ internal consistency was expected for the scale, as well as acceptable to high for the three factors (raw Cronbach's alpha $\geq 0.70$ ). ${ }^{20}$ Finally, the distributions of the factor scores could follow a normal distribution because these factors evaluate personality dimensions. ${ }^{21}$ 


\section{Patients and methods \\ Study setting and participants}

This cross-sectional study was conducted between May and June 2016. The sampling was nonprobabilistic. The intentional sample composed of 194 out of 400 HIV-positive patients receiving attention in a health care center of the National Program for the Control of AIDS (PRONASIDA, by its Spanish acronym), located in the city of Barquisimeto (Lara, Venezuela). The participation percentage was $90.6 \%$ (194 out of 214 persons who were invited). Eight out of 194 cases were dropped due to missing data. Therefore, the analyzed sample was composed of $186 \mathrm{HIV}$-positive persons, and sample proportion with respect to population was 0.465 (186 out of 400).

\section{Procedure}

This research was carried out taking into account the American Psychological Association's ethical principles ${ }^{22}$ and was approved by the Experimental Deanery of Humanities and Arts of the West-Central University "Lisandro Alvarado", as well as by the authorities of PRONASIDA. The participants were asked to read and sign informed consent. They completed the assessment during their scheduled clinical appointments with health personnel. For participants with low level of literacy, the scale was administered as a structured, face-to-face individual interview. We informed participants that the collected data would be used for research purposes, with the aim of contributing to the design of behavioral intervention programs to improve their psychological condition, as well as to promote the practice of treatment adherence and health care behaviors that are needed to ensure an optimal clinical control of the disease. Participants did not receive any economic compensation for their participation in the study.

\section{Measurement instruments}

The SRSS-12 is composed of 12 items with a 10-point Likert-type response scale ranging from $1=$ "no threatening at all" to $10=$ "extremely threatening". The questions were based on different functional criteria representing situations that people face from the moment they have been diagnosed with a chronic disease and require a long-term treatment. Prior to the administration of the SRSS-12, a linguistic revision was made by psychologists assigned by the Department of Psychology of the University West-Central "Lisandro Alvarado" (located in the same city), who made minor adjustments in the wording of the items. The final version of the scale is shown in Figure S1 and an English translation is shown in Figure S2. In their original version, the internal consistency of the 12 items was very high (raw Cronbach's alpha $=0.90$ ), and the SRSS-12 included three factors that explained the $70.5 \%$ of total variance: DM, TA, and TF/I. ${ }^{19}$

The treatment-adherence behavior was measured with one close-ended question related to the frequency of days (per week) in which the participants consumed their antiretroviral medication during last month. This question was used in the validation study of the Psychological Variables and Treatment-Adherence Behaviors Questionnaire performed in Venezuela. ${ }^{23}$ The answer options were as follows: $1=$ no day of the week; 2 few days of the week $(1-2$ days); $3=$ approximately half of the days of the week (3-4 days); $4=$ most days of the week (5-6 days); $5=$ every day of the week.

\section{Statistical analysis}

The first step included testing the expected three-factor (3F-E) model through CFA. The Pearson correlation matrix $(r)$ was used, being more adequate than that of polychoric correlations when the sample size is $<300$ participants. ${ }^{24}$ The multivariate distribution of the 12 items did not fit to a normal distribution (Mardia's multivariate asymmetry test: $\chi^{2}=200.889, P<0.001$; Mardia's multivariate kurtosis test: $\chi^{2}=365.109, P<0.001$, standardized value of Mardia's multivariate kurtosis $=15.145$ ), so the Scale-Free Least Squares was the method used to estimate the parameters, which does not assume multivariate normality and allows ordinal variables. The standard errors of the parameters were calculated by the Bias-Corrected Percentile method, extracting 2,000 bootstrap samples.

Six fit indices were considered: related chi-squared statistic $\left(\chi^{2} / d f\right)$, Standardized Root Mean Square Residual (SMSR), Jöreskog-Sörbom Goodness-of-Fit Index (GFI), Adjusted Goodness-of-Fit Index (AGFI), Bentler-Bonett Normed Fit Index (NFI), and Bollen's Relative Fit Index (RFI). The stipulated criteria for goodness of fit were $\chi^{2} / d f \leq 2$, SMSR $<0.08$, GFI, NFI, and RFI $\geq 0.95$, AGFI $\geq 0.90$, and the criteria for an acceptable fit were $\chi^{2} / d f \leq 3$, SMSR $<0.10$, GFI, NFI, and RFI $\geq 0.90$, AGFI $\geq 0.85 .{ }^{25}$ The parsimony of the model was estimated through the James-Mulaik-Brett Parsimony Ratio (PR). Values of PR $\geq 0.75$ were interpreted as high parsimony, $\geq 0.50$ as median, $\geq 0.25$ as low, and $<0.25$ as very low. ${ }^{25}$

Parsimonious index for NFI (PNFI) was calculated in relation to the independent model and for GFI (PGFI) in relation to the null model. PNFI values $\geq 0.80$ and $P G F I \geq 0.60$ were interpreted as good, whereas PNFI values $\geq 0.60$ and 
PGFI $\geq 0.50$ were considered as acceptable. It was considered that the goodness of fit between two models is equivalent when the quotient between the difference of the chi-squared statistic and the difference of the $d f$ of the models is less than or equal to $2\left(\Delta \chi^{2} / \Delta d f \leq 2\right)$, and the differences in the GFI, NFI, and RFI indices are $\leq 0.01 .^{25}$

We used an EFA to identify a model with better properties of discriminant validity and fit to data. The number of factors was determined through four methods: 1) Horn's parallel analysis (extracting 500 samples generated by permutation of the data and using the 95th percentile as the cut-point, 2) the Raiche-Roipel-Blais optimal coordinate (OC) method (with the same specifications of Horn's parallel analysis), 3) Velicer's minimum average partial, and 4) the Kaiser's criterion (eigenvalues $>1$ ). We were seeking the convergence of these four criteria. ${ }^{26}$ The factors were extracted through minimum residual method that allows ordinal variables and does not require multivariate normality. The factorial matrix was rotated using the promax method. ${ }^{24}$ We considered loads $>0.40$ to retain the variables. $^{24}$

Internal consistency was estimated using Cronbach's coefficient alpha for raw variables $(\alpha)$; values of $\alpha \geq 0.80$ were interpreted as high internal consistency, $\geq 0.70$ as adequate, $\geq 0.60$ as questionable, and $<0.60$ as low. ${ }^{27}$ In order to establish whether a factor had convergent validity, the average variance extracted (AVE), calculated as the mean of the squared factor loads, was required to be greater than or equal to 0.50 (AVE $\geq 0.50$ ). In order to establish whether two factors had discriminant validity, the AVE of each factor was required to be less than the square of the correlation between the two factors (shared variance), and less than two-thirds $\left(\mathrm{AVE}_{\mathrm{F} 1}\right.$ and $\left.\mathrm{AVE}_{\mathrm{F} 2}<\mathrm{r}_{\mathrm{F} 1 \mathrm{~F} 2}^{2}<0.667\right){ }^{28}$ To describe the distributions of factor scores, normality was tested by the Kolmogorov-Smirnov-Lilliefors test, and Fisher's kurtosis, skewness coefficients for samples, arithmetic mean, unbiased $\mathrm{SD}$, and quartiles were calculated. The central tendency of the three factors was also compared through the Wilcoxon's signed rank test.

\section{Results}

\section{Participants' characteristics}

The majority of patients were male $(80.1 \%)$, single $(76.3 \%)$, and with a bachelor degree (59.1\%). One-third had a CD4 cell count $>301$, while $41.4 \%$ had undetectable viral load and $54.8 \%$ reported to be following pharmacological therapy every day of the month. The average number of months since the HIV-positive diagnosis at the time of the survey was 62.9 $(\mathrm{SD}=63.0$; Table 1$)$.

\section{Factor structure, convergent and discriminant validity, and internal consistency}

The CFA of the 3F-E model yielded a permissible solution (Figure 1). All three factors had acceptable internal consistency: raw Cronbach's alpha $=0.79$ for TF/I, 0.78 for TA, and 0.78 for DM. The factors of DM and TA had convergent validity $\left(\mathrm{AVE}_{\mathrm{DM}}=0.587\right.$ and $\left.\mathrm{AVE}_{\mathrm{TA}}=0.554>0.50\right)$, but the $\mathrm{TF} / \mathrm{I}$ factor did not $\left(\mathrm{AVE}_{\mathrm{TF}}=0.396<0.50\right)$. The $\mathrm{DM}$ factor showed discriminant validity with respect to the TF/I factor $\left(\mathrm{AVE}_{\mathrm{DM}}=0.587\right.$ and $\left.\mathrm{AVE}_{\mathrm{TF}}=0.396>r^{2}[186]=0.111<0.667\right)$ and TA $\left(\mathrm{AVE}_{\mathrm{DM}}=0.587\right.$ and $\mathrm{AVE}_{\mathrm{TA}}=0.554>r^{2}[186]=0.169$ $<0.667)$. However, the factors of TA and TF/I lacked discriminant validity $\left(\mathrm{AVE}_{\mathrm{TF}}=0.396\right.$ and $\mathrm{AVE}_{\mathrm{TA}}=0.554<r^{2}$ $[186]=0.834>0.667)$. The goodness of fit of the model was good taking into account two indices (GFI $=0.95$ and AGFI $=0.93)$ and acceptable through four indices $\left(\chi^{2} / d f=2.30\right.$, NFI $=0.93, \mathrm{RFI}=0.91$, and standardized root mean square residual $(\mathrm{SRMR})=0.09)$. The model showed a high parsimony $(\mathrm{PR}$ $=0.77$ ), with acceptable parsimonious indices (PGFI $=0.62$ and PNFI $=0.71)$. The internal consistency of SRSS-12 was high $(\alpha=0.85)$.

Because of the problem of lack of discriminant validity, new models were proposed based on the EFA. The number of factors was two through Horn's parallel analysis and OC method. Based on the pattern and structure matrices, the configuration of two factors was as follows: $\mathrm{TF} / \mathrm{I}$ and TA (items from 1 to $9 ; \alpha=0.86$ ) and DM (items from 10 to $12 ; \alpha=0.78$ ). Using the Velicer's and Kaiser's criteria, the number of factors was three. Based on the pattern and structure matrices, the configuration of three factors was as follows: TF/I and TA (items 1, 2, 5, 6, and 7; $\alpha=0.82$ ); Follow-up of Instructions and Impulsivity (items 3, 4, 8, 9, and 10; $\alpha=0.78$ ); and DM (items 11 and 12; $\alpha=0.91$ ).

The two-factor model derived from EFA (2F-EFA) was tested; the solution was admissible (Figure 2). The DM factor showed convergent validity (AVE $=0.588)$, but the TF/I and TA factors did not $(\mathrm{AVE}=0.427)$. The percentage of shared variance between the two factors was $15.1 \%$, so there was discriminant validity. The goodness of fit of the model was good taking into account two indices (GFI $=0.95$ and AGFI $=0.93)$ and acceptable through four indices $\left(\chi^{2} / d f=2.28\right.$, NFI $=0.92$, RFI $=0.91$, and SRMR $=0.09)$. The model showed $\mathrm{a}$ high parsimony ( $\mathrm{PR}=0.80$ ) with acceptable parsimonious 
Table I Sociodemographic, clinical, psychological, and behavioral characteristics of participants

\begin{tabular}{|c|c|c|c|c|c|}
\hline Variables & $M$ & SD & Min/Max & $\mathbf{n}$ & $\%$ \\
\hline Age & 34.97 & 9.98 & $18-66$ & & \\
\hline \multicolumn{6}{|l|}{ Gender } \\
\hline Male & & & & 149 & 80.1 \\
\hline Female & & & & 37 & 19.9 \\
\hline \multicolumn{6}{|l|}{ Marital status } \\
\hline Single & & & & 142 & 76.3 \\
\hline Divorced & & & & 20 & 10.8 \\
\hline Married & & & & 19 & 10.2 \\
\hline Widowed & & & & 5 & 2.7 \\
\hline \multicolumn{6}{|l|}{ Schooling } \\
\hline Illiterate & & & & 4 & 2.2 \\
\hline Primary & & & & 11 & 5.9 \\
\hline Secondary & & & & 92 & 32.8 \\
\hline Bachelor & & & & 61 & 50.0 \\
\hline Postgraduate & & & & 17 & 9.1 \\
\hline Time since HIV+ diagnosis (months) & 62.90 & 63.09 & $6-492$ & & \\
\hline \multicolumn{6}{|l|}{ CD4 cell counts (cells $/ \mathrm{mL}$ ) } \\
\hline$<200$ & & & & 42 & 22.6 \\
\hline $201-300$ & & & & 81 & 43.5 \\
\hline$>301$ & & & & 63 & 33.9 \\
\hline \multicolumn{6}{|l|}{ Viral load (copies/mL) } \\
\hline Undetectable & & & & 77 & 41.4 \\
\hline$<1,00,000$ & & & & 76 & 40.9 \\
\hline$>1,00,000$ & & & & 33 & 17.7 \\
\hline \multicolumn{6}{|l|}{ Personality factors } \\
\hline Tolerance to Frustration and Ambiguity & 3.80 & 2.21 & $1-10$ & & \\
\hline Follow-up of Instructions and Impulsivity & 3.97 & 2.06 & $1-10$ & & \\
\hline Decision Making & 5.31 & 2.41 & $1-10$ & & \\
\hline \multicolumn{6}{|l|}{ Adherence behaviors (weeks) } \\
\hline Few days ( $I-2$ days) & & & & 25 & 13.4 \\
\hline Most of the days (5-6 days) & & & & 59 & 31.7 \\
\hline All days (7 days) & & & & 102 & 54.8 \\
\hline
\end{tabular}

Note: Sample size $(N)=186$.

Abbreviations: $M$, mean; Min, minimum value; Max, maximum value; $n$, simple absolute frequency.

indices (PGFI $=0.65$ and PNFI $=0.74$ ). The goodness of fit of this model was equivalent to that of the expected threefactor model $\left(\Delta \chi^{2} / \Delta \mathrm{gl}=3.522 / 2=1.761<2\right.$ and; $\Delta \mathrm{GFI}, \Delta \mathrm{AGFI}$, $\Delta \mathrm{NFI}$, and $\Delta \mathrm{RFI}<0.01)$.

The three-factor model derived from EFA (3F-EFA) presented a problem related to having an insufficient number of indicators in the DM factor. Taking into account that item 10 of the Follow-up of Instructions and Impulsivity factor had its second highest load and was $>0.40$ in the DM factor, this item was taken as an indicator of both factors. Thus, the minimum of three indicators was reached, and the factor coincided in its configuration with the expected factor (items 10, 11, and 12). When testing this three-factor model (3F-EFA), the solution was admissible (Figure 3).

The three factors had convergent validity (TFA [AVE $=0.692$, Follow-up of Instructions and Impulsivity [AVE
$=0.608]$, and DM [AVE $=0.720]$ ). The shared variance ranged from 0.57 to 0.56 , so all the three factors showed discriminant validity. The goodness of fit was good through five indices $\left(\chi^{2} / d f=1.47, \mathrm{SRMR}=0.07, \mathrm{GFI}=0.97, \mathrm{AGFI}=0.95\right.$, and NFI $=0.95)$ and acceptable through one index $(\mathrm{RFI}=0.94)$. The model showed a high parsimony $(\mathrm{PR}=0.72)$ with acceptable parsimonious indices $(\mathrm{PGFI}=0.62$ and $\mathrm{PNFI}=0.75$ ). When comparing the $3 \mathrm{~F}-\mathrm{EFA}$ model with the two previous models, the former model showed higher goodness of fit $\left(\Delta \chi^{2} / \Delta \mathrm{gl}>2\right.$ and $\Delta \mathrm{GFI}, \Delta \mathrm{AGFI}, \Delta \mathrm{NFI}$, and $\Delta \mathrm{RFI}>0.01)$.

\section{Distributions of factor scores}

Based on the new factor model, scores on the TFA factor were obtained by adding items 1, 2, 5, 6 and 7. Scores on the Follow-up of Instructions/Impulsivity (FII) factor were obtained by adding items 3, 4, 8, 9 and 10. Finally, scores 


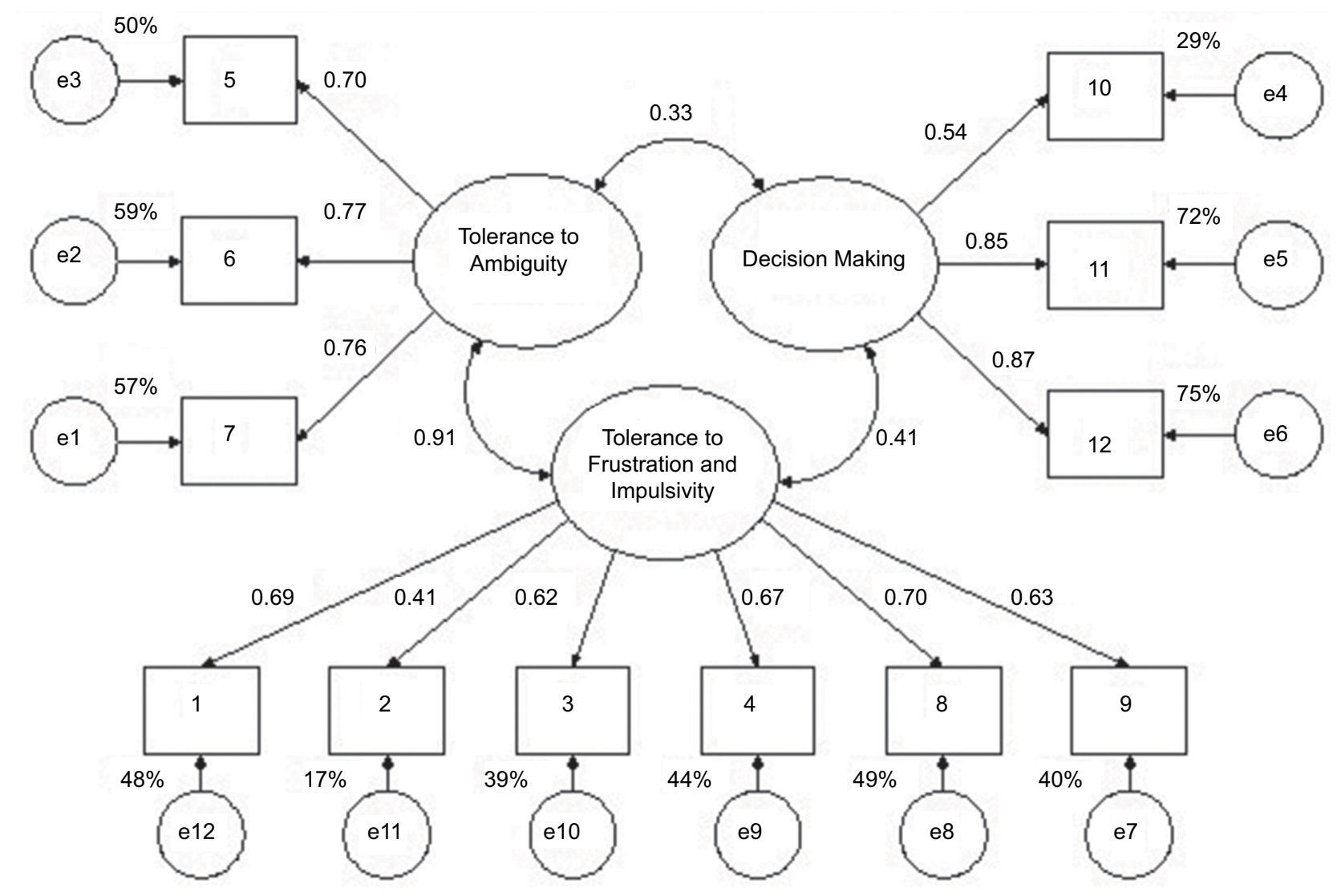

Figure I Expected three-factor (3F-E) model.

Note: el-el 2 measurement residuals.

on the DM factor were obtained by adding items 10,11 , and 12 . Then the sums were divided by the number of added items; in this way the score range was from 1 to 10 . The distribution of TFA scores showed positive asymmetry $(\mathrm{Sk}=0.47,95 \% \mathrm{CI}: 0.12,0.82)$ and platykurtosis $(\mathrm{K}=-0.78$, 95\% CI: $-1.48,-0.09$ ); the distribution of FII scores also showed positive asymmetry ( $\mathrm{Sk}=0.64,95 \% \mathrm{CI}: 0.30,0.99$ ), but was mesokurtic ( $\mathrm{K}=-0.585,95 \% \mathrm{CI}:-1.21,0.11)$. The distribution of DM scores was symmetric ( $\mathrm{Sk}=0.30,95 \% \mathrm{CI}$ : $-0.05,0.64)$, but showed platykurtosis $(\mathrm{K}=-1.10,95 \% \mathrm{CI}$ : $-1.80,-0.41)$. No distribution followed a normal distribution based on the Kolmogorov-Smirnov-Lilliefors test.

The TFA average (arithmetic mean $[\mathrm{M}]=3.80,95 \% \mathrm{CI}$ : $3.48,4.12$ ) was not statistically different (Wilcoxon signed rank test: $\mathrm{Z}=-0.89, P=0.375)$ to FII average $(\mathrm{M}=3.97,95 \%$ CI: $3.68,4.27)$. Nevertheless, these two averages were significantly lower $(\mathrm{Z}=-6.20, P<0.001$ and $\mathrm{Z}=-7.14, P<0.001$, respectively) than DM average ( $M=4.96,95 \%$ CI: 5.66, 4.12).

By dividing this continuous range into ten intervals of constant amplitude in correspondence with the ten ordinal values of the response to the items, the response labels to the items can be used to interpret the scores and means in the factors: $[1,1.9] \rightarrow 1=$ "not at all threatening", [1.9, 2.8] $\rightarrow 2=$ "almost nothing threatening", $[2.8,3.7] \rightarrow 3=$ "very little threatening", $[3.7,4.6] \rightarrow 4=$ "little threatening", [4.6, $5.5] \rightarrow 5=$ "more or less threatening", [5.6, 6.4] $\rightarrow 6=$ "something threatening", $[6.4,7.3] \rightarrow 7=$ "quite threatening", $[7.5,8.2] \rightarrow 8=$ "decidedly threatening", [8.2, 9.1] $\rightarrow 9=$ "very threatening", and $[9.1,10] \rightarrow 10=$ "extremely threatening". Consequently, the arithmetic means of TFA and FII in the interval $[3.7,4.6])$ corresponded to "little threatening" (4), and the arithmetic mean of MD in the interval $[4.6,5.5])$ corresponded to "more or less threatening" (5). The median for TFA ( $\mathrm{Mdn}=3.6$, first quartile $\left[\mathrm{Q}_{1}\right]=1.8$ and third quartile $\left.\left[\mathrm{Q}_{3}\right]=5.4\right)$ and FII $\left(\mathrm{Mdn}=3.6, \mathrm{Q}_{1}=2\right.$ and $\left.\mathrm{Q}_{3}=5.6\right)$ corresponded with an interval lower than the one of their arithmetic means $([2.8,3.7] \rightarrow 3=$ very little threatening). The Mdn for DM corresponded with the same interval than the one of its arithmetic mean $\left(\mathrm{Mdn}=4.83, \mathrm{Q}_{1}=3.33\right.$ and $\mathrm{Q}_{3}=7.33$ ). 


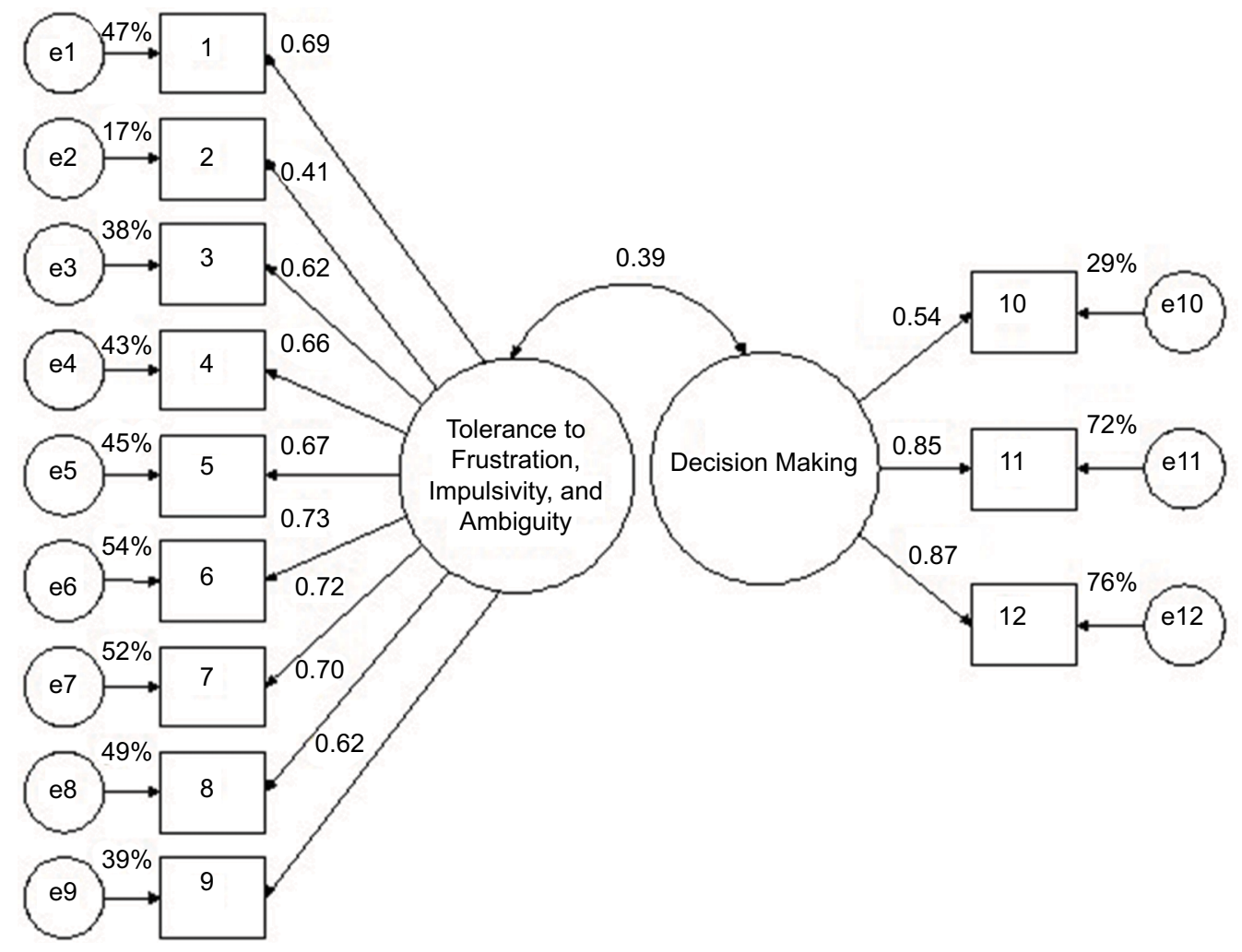

Figure 2 Two-factor model derived from EFA.

Note: el-el 2 measurement residuals.

Abbreviation: EFA, exploratory factor analysis.

\section{Discussion}

When testing the expected three-factor model, it was revealed that there was a problem of discriminant validity between the TA factor and the Tolerance to Frustration factor, since the correlation between them was $>0.90$. This finding led to a subsequent analysis with the aim of finding a new factor structure in which the factors had not only convergent and discriminant validity but also a high internal consistency. On the one hand, the EFA offered evidence of a two-factor model that matches the results reported in Peruvian women with breast cancer. ${ }^{20}$ In the present study and Peruvian study, the TA factor and the Tolerance to Frustration factor merged into one single factor.

This finding might be explained by the fact that the stress associated with living with a chronic disease and the prescription of long-term therapies demands extensive personal resources ${ }^{29}$ and TFA might become essential in this context, since the therapeutic program not only includes medication adherence but also a change of the life style (diet, exercise and hours of sleeping). ${ }^{30,31}$ It should be noted that the two-factor model was supported by Horn's Parallel Analysis and by Raiche-Roipel-Blais OC method, which are considered the most solid strategies for determining the number of factors. ${ }^{26}$ On the other hand, the EFA revealed a three-factor structure; in this model, the two factors with insufficient discriminant validity had a different configuration; one of these factors was composed of items related to TFA, while the other one was composed of items related to Follow-up of Instructions and Impulsivity.

It is important to remark that one of the items included in the DM factor (item 10) had its highest load (close to 0.50) on the Follow-up of Instructions and Impulsivity factor, while its second highest load (and $>0.40$ ) was found on its expected location, within the DM factor. This caused that, in the CFA, this item became an indicator of both factors (cross loading), so that the DM factor could be defined by, at least, three indicators, as it is recommended for the factor analysis. ${ }^{24,25}$ This specification allowed obtaining a model that showed appropriate goodness of fit (from good to acceptable with a domain of good fit values), had convergent and discriminating validity on its factors, as well as good internal consistency. It will be necessary to analyze in future studies the conceptual structure of this model, including persons living with HIV and persons suffering from other chronic diseases (eg, diabetes, 


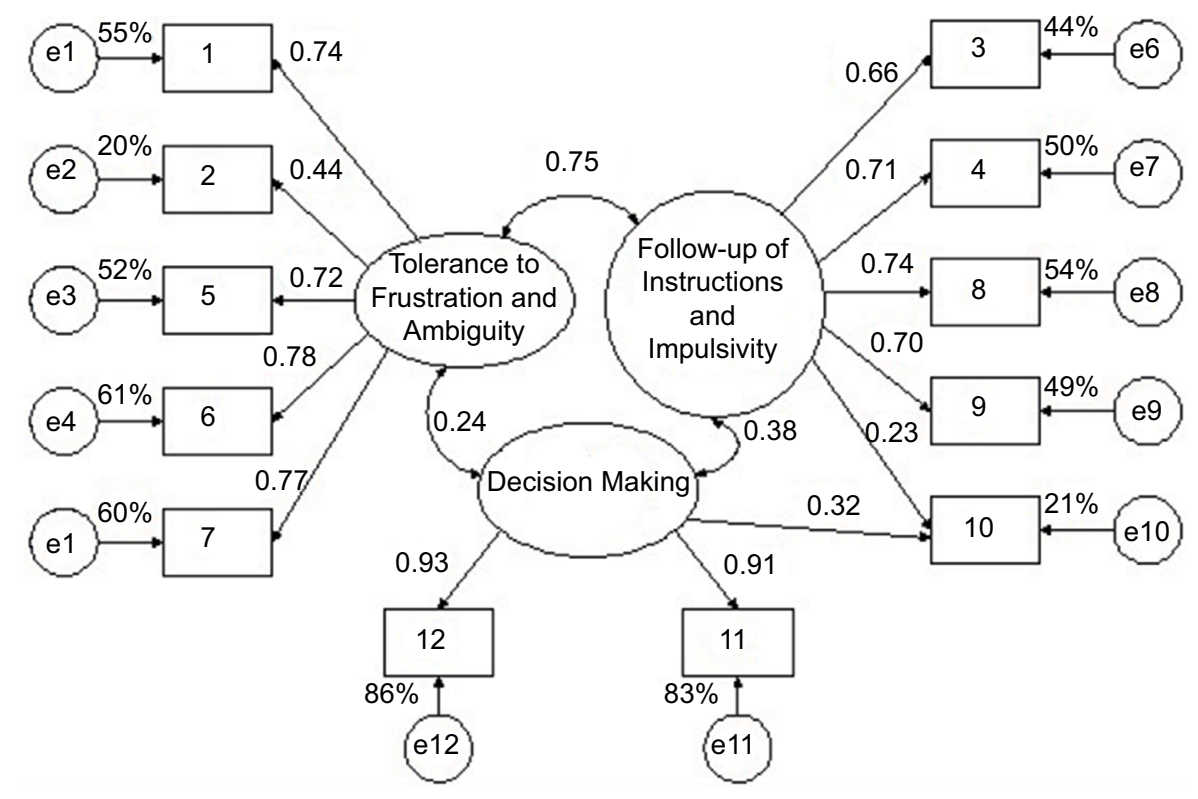

Figure 3 Three-factor model derived from EFA.

Note: el-el 2 measurement residuals.

Abbreviation: EFA, exploratory factor analysis.

cardiovascular diseases and cancer), in order to identify the magnitude and the way in which this model applies to the assessment of the different dimensions that have been studied in this research.

When comparing the two-factor model and the threefactor model derived from EFA, the latter one had the best values of internal consistency, AVE, and goodness of fit, in addition to showing high parsimony. Furthermore, the threefactor model showed discriminant validity, and its contents were clearly interpretable. The three factors can be justified through Kaiser's criterion, although Kaiser's criterion tends to be discouraged to determine the number of factors because it does not take into account sampling error. ${ }^{26}$ Velicer's analysis also holds that there were three substantive factors that were explaining shared variance and not the spurious variance. ${ }^{26}$ Therefore, all these findings together ensure that the threefactor model is the best solution.

Because the scale was developed in light of a theoretical model, ${ }^{8,9,15}$ it is necessary to clarify if these variables of personality should be considered as a part of a set of psychological variables, including the motives to behave and the behavioral competencies. Therefore, the potential implications of the findings reported here and for subsequent studies, lie in the probability of obtaining accurate information about how it is that the variables of the most distal (personality) and the most recent (motives and behavioral competencies) history interact facilitating or limiting the practice of the medication adherence and health care behaviors. In that sense, the type of intervention program that is designed to improve the psychological condition and the practice of both types of behaviors will depend on the way in which the personality variable modulates the operation of motives and behavioral competencies. The research background based on the theoretical model constitutes a reference that is now taken into account in the context of the disease rehabilitation, as are the cases of HIV/ AIDS, diabetes, cancer, and hypertension..$^{32-36}$

This study showed that the situations of Ambiguity due to secondary effects, efficacy of medication, and control of the irritability generated by treatment adherence and Follow-up of Instructions were little threatening, but situations that involve Decision Making about other options of treatment (home remedies and naturopathy) are more or less threatening. Therefore, it seems that patients feel calm and confident in their medical treatment, and feel stressed by any questioning of their current treatment, as shown by studies on satisfaction with antiretroviral therapy. ${ }^{37}$

At least three limitations should be considered in our study. First, since we worked with a nonprobabilistic sample the results do not constitute estimates of population parameters, but should be handled as hypotheses in future studies. Second, the size of the sample did not reach the minimum of 200 recommended for performing CFA, partly owing to the characteristics of the institution in which the study was performed; however, there were more than 15 participants per 
item, more than 5 participants per estimated parameter, and the average effect size of the factors on their indicators was high. Third, because the sample was restricted to HIV-positive cases without meeting AIDS criteria, any generalization of the results to cases with AIDS requires further demonstration. Strengths of the study are the use of appropriate analysis techniques for ordinal variables that do not fulfill multivariate normality, as well as the use of rigorous methods to determine the number of factors in the EFA.

\section{Conclusion}

The internal consistency of the scale was high, not requiring the elimination of any item. The expected three-factor model showed a severe problem of discriminant validity in two of its factors. The convergence of criteria for determining the number of factors indicated the existence of two factors (parallel analysis and OC method) or three factors (Velicer's and Kaiser's criteria). In the two-factor model, one of the factors lacked convergent validity, and the goodness-of-fit indices with values not beyond the acceptable range prevailed; in this model, the two factors without discriminant validity from the expected three-factor model were merged into one. In the new three-factor model specified in this research and derived from EFA, the three factors had convergent and discriminant validity, values of internal consistency varied from acceptable to high, the goodness of fit was good, and the goodness of fit of this model was greater than the one of other two models; thus, this last model would be the best option. In this model, the two factors without discriminant validity from the expected three-factor model showed a different configuration. The distributions of factor scores did not follow a normal curve, so that can be scaled using percentile scores.

In future studies, it is suggested to test the new threefactor model (TFA [items 1, 2, 5, 6, and 7], Follow-up of Instructions and Impulsivity [items 3, 4, 8, 9, and 10], and DM [items 10, 11, and 12]), using multigroup analysis across gender (women vs men) and different clinical populations (HIV-positive patients vs AIDS patients), reaching a minimum size of 200 participants per group. As a new step in the adaptation of the SRSS-12, researchers could estimate the norms and cutoff points to interpret the raw scores on the scale and its factors. For this purpose, probability sampling should be used; likewise, two groups could be distinguished: one with adherence to treatment and another without adherence to treatment.

Another suggestion would be to perform a systematic study of the personality variables in relation to other psychological processes or variables included in the personality theory on interactive styles (eg, motives, behavioral competencies, and mood states), ${ }^{38}$ in order to obtain specific indicators of their joint influence on the function of the immune system and other biological markers among people living with HIV. Finally, the main goal shall be to achieve valid and reliable information that allows us to design, implement, and evaluate theoretically justified behavioral intervention programs to promote or improve the efficient and consistent practice of therapy adherence and health care behaviors in persons living with HIV in Venezuela. ${ }^{39,40}$

\section{Acknowledgments}

The authors express their acknowledgements to the authorities of the National Program of HIV/AIDS in Lara, Venezuela, and thank the decisive participation of the HIV-positive patients.

\section{Author contributions}

JMR contributed to the statistical analyses and drafted the article. GPCA and ACTY designed the study, conducted extensive medical record review, and prepared preliminary analysis. VMLG reviewed the study protocol, prepared preliminary analysis, and drafted the article. JAPL and JLYS selected references and contributed to subsequent revisions of the draft. All authors contributed toward data analysis, drafting and critically revising the paper, gave final approval of the version to be published, and agree to be accountable for all aspects of the work.

\section{Disclosure}

The authors report no conflicts of interest in this work.

\section{References}

1. Hori R, Hayano J-I, Kimura K, Shibata N, Kobayashi F. Psychosocial factors are preventive against coronary events in Japanese men with coronary artery disease: The Eastern Collaborative Group Study 7.7year follow-up experience. Biopsychosoc Med. 2015;9(1):3.

2. Molloy GJ, O’Carroll RE, Ferguson E. Conscientiousness and medication adherence: a meta-analysis. Ann Behav Med. 2014;47(1):92-101.

3. Sánchez MJ, García JM, Valverde M, Pérez-Álvarez M. Chronic illness: life satisfaction and adaptative personality styles. Clin Salud. 2014;25(2):85-93.

4. Sutin AR, Terracciano A. Five-factor model personality traits and the objective and subjective experience of body weight. J Pers. 2016;84(1):102-112.

5. Chesney MA, Morin M, Sherr L. Adherence to HIV combination therapy. Soc Sci Med. 2000;50(11):1599-1605.

6. Penedo FJ, Gonzalez JS, Dahn JR, et al. Personality, quality of life and HAART adherence among men and women living with HIV/AIDS. $J$ Psychosom Res. 2003;54(3):271-278.

7. Ironson GH, O'Cleirigh C, Weiss A, Schneiderman N, Costa PT. Personality and HIV disease progression: role of NEO-PI-R openness, extraversion, and profiles of engagement. Psychosom Med. 2008;70(2):245-253.

8. Ribes E. What should be measured in Psychology: the issue of individual differences. Acta Comport. 2005;13(1):37-52. 
9. Ribes E, Sánchez S. The problem of individual differences: a conceptual analysis of personality. In: Ribes E, editor. General Psychology. México: Trillas; 1990:231-253.

10. Ryle G. The Concept of Mind. New York: Barnes and Noble; 1949.

11. Ribes E, Contreras S, Martínez C, Doval E, Viladrich C. Individual consistencies across time and tasks: a replication of interactive styles. Psychol Rec. 2005;55(4):619-631.

12. Arend I, Botella J, Contreras MJ, Hernández JM, Santacreu J. A betting dice test to study the interactive style of risk-taking behavior. Psychol Rec. 2003;53(2):217-230.

13. Ribes-Iñesta E, Contreras S. Individual consistencies in behavior: Achievement persistence interactions as personality styles. Psychol Rep. 2007;101(2):365-377.

14. Moreno L, Hernández JM, García O, Santacreu J. Computerized test for the tolerance to frustration assessment. An Psicol. 2000;16(2):143-155.

15. Fuentes EN. Experimental Proposal to Study the Interactive Style Tolerance to Ambiguity. Master in Science unpublished thesis. Guadalajara, México: Universidad de Guadalajara; 2011.

16. Piña JA, Sánchez-Sosa JJ. Psychological model for investigation of therapeutic compliance behaviors in people with HIV. Univ Psychol. 2007;6(2):399-407.

17. Piña JA, Corrales AE, Mungaray K, Valencia MA. Instrument for measuring psychological variables and adherence to treatment behavior in persons who are seropositive for HIV (VPAD-24). Pan Am J Public Health. 2006;19(4):217-228.

18. Piña JA, Valencia MA, Mungaray K, Corrales AE. Validación de una escala breve que mide situaciones vinculadas con estrés en personas VIH positivas [Validation of a short scale that measures stress related events in HIV positive patients]. Ter Psicol. 2006;24(1):15-21. Spanish.

19. Piña JA, Valencia MA, Mungaray K, Corrales AE. Validation of a short scale that measures stress-related events in HIV positive patients. Ter Psicol. 2006;24(1):15-21.

20. Piña JA, Mejía R, Méndez J, Laborín JF. Peruvian version of a scale measuring stress-related situations (SRS-12) among breast cancer women. Rev Latinoam Med Cond. 2014;4(2):74-82.

21. Matthews G, Deary IJ, Whiteman MC. Personality Dimensions. 2nd ed. Cambridge: Cambridge University Press; 2003.

22. American Psychological Association. Ethical Principles of Psychologists and Code of Conduct. Washington, DC: APA; 2016.

23. Álvarez EM, González RD, Miaja M, Piña JA, Fierros LE. Validation of a brief questionnaire for assessing psychological variables and medication-adherence behaviors among HIV-positive persons from Venezuela. Rev Latinoam Med Cond. 2015;5(1):1-8.

24. Lloret-Segura S, Ferreres-Traver A, Hernández-Baeza A, Tomás-Marco I. Exploratory item factor analysis: a practical guide revised and updated. An Psicol. 2014;30(3):1151-1169.
25. Byrne BM. Structural Equation Modeling with Amos: Basic Concepts, Applications, and Programming. 3rd ed. New York: Routledge; 2016.

26. Courtney MGR. Determining the number of factors to retain in EFA: using the SPSS R-Menu v2.0 to make more judicious estimations. Practical Assess Res Eval. 2013;18(8):1-13.

27. Bolarinwa OA. Principles and methods of validity and reliability testing of questionnaires used in social and health science researches. Niger Postgrad Med J. 2015;22(4):195-201.

28. Malhotra NK, Dash S. Marketing Research an Applied Orientation. London: Pearson Publishing; 2011.

29. Urzúa A, Caqueo-Urízar A, Quiceno JM, Alpi SV, Pavlov N. Do personal resources influence health-related quality of life for people receiving hemodialysis treatment in Latin America? Soc Behav Pers. 2015;43(3):367-382.

30. Brown MT, Bussell JK. Medication adherence: WHO cares? Mayo Clin Proc. 2011;86(4):304-314.

31. Jin J, Sklar GE, Min Sen Oh V, Chuen Li S, Vms O, Sc L. Factors affecting therapeutic compliance: a review from the patient's perspective. Ther Clin Risk Manag. 2008;4(1):269-286.

32. Sagarduy JLY, López JAP, Ramírez MTG, et al. Psychological model of ART adherence behaviors in persons living with HIV/AIDS in Mexico: a structural equation analysis. Rev Saude Publica. 2017;51:81.

33. Piña JA, Torres AM. Stress-related situations as predictors of adherenceto-medication behavior among women with type 2 diabetes. Int J Hisp Psychol. 2008;1(1):75-84.

34. Méndez J, Mejía R, Laborín JF, Piña JA. Adherence among breast women from Peru. Gac Mex Oncol. 2014;13(2):117-123.

35. Camacho DY, Ybarra JL, Masud JL, Piña JA. Adherence to treatment in hypertensive patients with overweight and obesity. Rev Int Psicol Ter Psicol. 2015;15(3):377-386.

36. Piña JA, Moral J, Ybarra JL, Camacho DY, Masud JL. Consumption of restricted foods among Mexican hypertensive patients: a trajectory analysis. Nutr Hosp. 2017;34(6):1044-1051

37. Wung BA, Peter NF, Atashili J. Clients' satisfaction with HIV treatment services in Bamenda, Cameroon: a cross-sectional study. BMC Health Serv Res. 2016;16:280.

38. Ribes E. Psychology and Health: A Conceptual Analysis [In Spanish]. Martínez Roca: Barcelona; 1990.

39. Elzarrad MK, Eckstein ET, Glasgow RE. Applying chronic illness care, implementation science, and self-management support to HIV. Am J Prev Med. 2013;44(1):S99-S107.

40. Wood CE, Hardeman W, Johnston M, Francis J, Abraham C, Michie S. Reporting behaviour change interventions: Do the behaviour change technique taxonomy v1, and training in its use, improve the quality of intervention descriptions? Implement Sci. 2016;11(1):84-95. 


\section{Supplementary materials}

A continuación se le presentan una serie de preguntas que tienen que ver situaciones que usted eventualmente enfrenta día a día. En una escala del 1 al 10, indíquenos como evalúa usted qué tan amenazantes le resultan esas situaciones, donde 1 es igual a nada amenazante y 10 es igual a demasiado amenazante.

\begin{tabular}{|c|c|}
\hline Situaciones & ¿Qué tan amenazante es esto? \\
\hline $\begin{array}{l}\text { I. Usted se encuentra recibiendo tratamiento médico y sigue las instrucciones tal y como se lo indicó su } \\
\text { médico, pero no observa mejoras inmediatas en su salud; entonces ello le resulta: }\end{array}$ & 12345678910 \\
\hline $\begin{array}{l}\text { 2. El tratamiento médico que recibe exige que usted haga diferentes cosas (Por ejemplo: tomar } \\
\text { medicamentos, acudir a citas periódicas, hacerse pruebas de laboratorio, cambiar su estilo de vida, } \\
\text { etcétera); entonces ello resulta: }\end{array}$ & 12345678910 \\
\hline $\begin{array}{l}\text { 3. A pesar de que usted cumple con el tratamiento médico, es decir, que hace todo lo que su médico le } \\
\text { indicó, no recibe respuestas positivas o apoyo por parte de su médico; entonces ello le resulta: }\end{array}$ & 12345678910 \\
\hline $\begin{array}{l}\text { 4. A pesar de que usted cumple con el tratamiento médico, es decir, que hace todo lo que su médico le } \\
\text { indicó, no recibe respuestas positivas o apoyo por parte de otras personas; entonces ello le resulta: }\end{array}$ & 12345678910 \\
\hline $\begin{array}{l}\text { 5. A usted se le diagnosticó una enfermedad que no sabe si tendrá cura en el corto o mediano plazo, } \\
\text { entonces ello le resulta: }\end{array}$ & 12345678910 \\
\hline $\begin{array}{l}\text { 6. Usted se encuentra recibiendo tratamiento médico, pero no sabe si el tratamiento va a ser realmente } \\
\text { efectivo y le ayudará a controlar o curar su enfermedad; entonces ello le resulta: }\end{array}$ & 12345678910 \\
\hline $\begin{array}{l}\text { 7. Usted se encuentra recibiendo tratamiento, pero no sabe si el tratamiento va a tener efectos } \\
\text { desagradables; entonces ello le resulta: }\end{array}$ & 12345678910 \\
\hline $\begin{array}{l}\text { 8. Usted se encuentra recibiendo tratamiento y su médico le pide que realice ciertos cambios en su vida, } \\
\text { pero le cuesta trabajo hacer lo que le piden, causando que responda impulsivamente; entonces ello le } \\
\text { resulta: }\end{array}$ & 12345678910 \\
\hline $\begin{array}{l}\text { 9. Usted se encuentra recibiendo tratamiento y su médico le pide que realice ciertos cambios en su vida, } \\
\text { pero sus familiares o amigos cercanos influyen en usted y no realiza los cambios esperados porque se } \\
\text { siente que es presionado demasiado; entonces ello le resulta: }\end{array}$ & 12345678910 \\
\hline $\begin{array}{l}\text { 10. Usted se encuentra en tratamiento y su médico le da indicaciones que debe seguirlas al pie de la letra, } \\
\text { pero usted no entiende lo que su médico le pide; entonces ello le resulta: }\end{array}$ & 12345678910 \\
\hline $\begin{array}{l}\text { II. Usted se encuentra en tratamiento y su médico le da indicaciones que debe seguirlas al pie de la } \\
\text { letra, pero usted toma la decisión de seguir con otro tratamiento diferente, como por ejemplo, tomar } \\
\text { remedios caseros, seguir un tratamiento naturista o seguir los consejos de alguna persona que no es su } \\
\text { médico; entonces ello le resulta: }\end{array}$ & 12345678910 \\
\hline $\begin{array}{l}\text { 12. Usted se encuentra en tratamiento y su médico le da indicaciones que debe seguirlas al pie de la letra, } \\
\text { pero sus familiares o amigos cercanos sugieren seguir con otro tratamiento diferente, como por ejemplo, } \\
\text { tomar remedios caseros, seguir un tratamiento naturista o seguir los consejos de alguna persona que no } \\
\text { es su médico; entonces ello le resulta: }\end{array}$ & 12345678910 \\
\hline
\end{tabular}

Figure SI The 12-item Stress-Related Situations Scale (Venezuelan adaption in Spanish).

Notes: Adapted from Piña JA, Valencia MA, Mungaray K, Corrales AE. Validación de una escala breve que mide situaciones vinculadas con estrés en personas VIH positivas [Validation of a short scale that measures stress related events in HIV positive patients]. Ter Psicol. 2006;24(I):15-21. Spanish. Copyright 2006 by Sociedad Chilena de Psicología Clínica.' This Venezuelan version of the SRSS-12 was adapted by psychologists assigned by the Department of Psychology of the University West-Central "Lisandro Alvarado", who made minor adjustments in the wording of the items and instructions (highlighted in blue). 
Below, a series of questions about situations that you eventually face day by day are presented. On a scale from 1 to 10, tell us how you evaluate how threatening these situations are, where 1 means not at all threatening, 5 more or less threatening, and 10 extremely threatening.

\begin{tabular}{|c|c|}
\hline Situations & How threatening is it? \\
\hline $\begin{array}{l}\text { I. You are receiving medical treatment and are following the instructions as directed by your doctor, but do not } \\
\text { see immediate improvements in your health; so that you find it to be: }\end{array}$ & 12345678910 \\
\hline $\begin{array}{l}\text { 2. You are being treated and health provider asks you to practice different behaviors (for example: taking } \\
\text { medications, attending regular appointments, doing laboratory tests, changing your lifestyle, etc.), but you do not } \\
\text { perceive positive consequences from doing that; so that you find it to be: }\end{array}$ & 12345678910 \\
\hline $\begin{array}{l}\text { 3. Although you are complying with medical treatment, that is, that you are doing everything your doctor told you, } \\
\text { you do not receive positive answers or support from your doctor; so that you find it to be: }\end{array}$ & 12345678910 \\
\hline $\begin{array}{l}\text { 4. Even though you are complying with medical treatment, that is, you are doing everything your doctor told you, } \\
\text { you do not receive positive responses or support from other people; so that you find it to be: }\end{array}$ & 12345678910 \\
\hline $\begin{array}{l}\text { 5. You have been diagnosed with a disease that does not know if you will have a cure in the short or medium term, } \\
\text { so that you find it to be: }\end{array}$ & 12345678910 \\
\hline $\begin{array}{l}\text { 6. You are receiving treatment, but you do not know if it will be effective and will help you to control or cure your } \\
\text { disease; so that you find it to be: }\end{array}$ & 12345678910 \\
\hline $\begin{array}{l}\text { 7. You are receiving treatment, but do not know if the treatment is going to have unpleasant effects; so that you } \\
\text { find it to be: }\end{array}$ & 12345678910 \\
\hline $\begin{array}{l}\text { 8. You are receiving treatment, which requires you to make certain changes in your life, but it is difficult for you to } \\
\text { do what they ask for, causing you to respond impulsively; so that you find it to be: }\end{array}$ & 12345678910 \\
\hline $\begin{array}{l}\text { 9. You are being treated and your doctor asks you to make certain changes in your life, but your family or close } \\
\text { friends influence you, and you do not make the changes expected because you feel you are being pressured too } \\
\text { much; so that you find it to be: }\end{array}$ & 12345678910 \\
\hline $\begin{array}{l}\text { 10. You are being treated and your doctor gives you indications that you must follow them carefully, but you do } \\
\text { not understand what your doctor asks for; so that you find it to be: }\end{array}$ & 12345678910 \\
\hline $\begin{array}{l}\text { II. You are being treated and your doctor gives you instructions that you must follow carefully, but you make the } \\
\text { decision to follow other different treatment, such as taking home remedies, naturopathic therapy, or following the } \\
\text { advice of someone who is not your doctor, etc.; so that you find it to be: }\end{array}$ & 12345678910 \\
\hline $\begin{array}{l}\text { 12. You are being treated and your doctor gives you instructions that you must follow carefully, but your family or } \\
\text { close friends suggest continuing with another treatment, such as taking home remedies, following a naturopathic } \\
\text { treatment or following advice from someone who is not your doctor; so that you find it to be: }\end{array}$ & 12345678910 \\
\hline
\end{tabular}

Figure S2 The 12-item Stress-Related Situations Scale (English translation of the Venezuelan adaption).

Notes: Translated and adapted from Piña JA, Valencia MA, Mungaray K, Corrales AE. Validación de una escala breve que mide situaciones vinculadas con estrés en personas VIH positivas [Validation of a short scale that measures stress related events in HIV positive patients]. Ter Psicol. 2006;24(I): I5-2I. Spanish. Copyright 2006 by Sociedad Chilena de Psicología Clínica.' This English version of the SRSS-12 was adapted by psychologists assigned by the Department of Psychology of the University West-Central "Lisandro Alvarado". Minor adjustments in the wording of the items and instructions have been done. The translation was conducted by the authors of this article.

\section{Reference}

1. Piña JA, Valencia MA, Mungaray K, Corrales AE. Validación de una escala breve que mide situaciones vinculadas con estrés en personas VIH positivas [Validation of a short scale that measures stress related events in HIV positive patients]. Ter Psicol. 2006;24(1):15-21. Spanish.

Psychology Research and Behavior Management

\section{Dovepress}

\section{Publish your work in this journal}

Psychology Research and Behavior Management is an international, peerreviewed, open access journal focusing on the science of psychology and its application in behavior management to develop improved outcomes in the clinical, educational, sports and business arenas. Specific topics covered in the journal include: Neuroscience, memory and decision making; Behavior modification and management; Clinical applications; Business and sports performance management; Social and developmental studies; Animal studies. The manuscript management system is completely online and includes a very quick and fair peer-review system, which is all easy to use. Visit http://www. dovepress.com/testimonials.php to read real quotes from published authors. 